Article received on August $8^{\text {th }} 2015$

Article accepted on October $15^{\text {th }} 2015$

UDC: 7.01

82.0

\title{
Dragana Stojanović*
}

Faculty of Media and Commuincations

"Singidunum" University, Belgrade

\section{STRATEGIES OF WORKING WITH THE SONOROUS BODY: IDENTIFYING OTHER/NEW WRITING TECHNIQUES IN THE FIELD OF BODILY SOUND EXPRESSION}

\begin{abstract}
The issue of the entanglement and interdependence of corporeality and textuality in the process of creating writing attracts attention both in the field of sound and of semantic and bodily expression in sound. When the body is established in the process of semanticization (and re-semanticization), as a specific threshold of writing, the place and role of the sonorous body forms the focus of theoretical research in that discursive space. This text explores the body's relational connection with writing, focusing on the always present transformative potential of speaking writing (again) as a consequence and condition of bodily expression in sound.
\end{abstract}

Keywords: the body, corporeality, textuality, writing, working with writing aloud.

The complexity of the relational connection between the place of the voice, the body, and writing is increasingly attracting attention in the domain of contemporary theories of sonorous corporealities and textualities. ${ }^{1}$ As the body is not only a place of images, ${ }^{2}$ but also a place of sounds (of the voice, of vocalizing, of sounding), ${ }^{3}$ so the Other, in the process of subjection viewed from the platform

\footnotetext{
* Author contact information: dragana.stojanovic@fmk.edu.rs

1 See Jelena Novak's discussion in Postopera: Reinventing the Voice-body, Farnham (UK), Ashgate, 2015.

2 The place that sees an image (of itself, through an other), which calls (upon) her from the place of the Other in the form of presenting the body as the symbolic carrier of subjectivity.

3 "“A voice means this: there is a living person, throat, chest, feelings, who sends into the air this voice, different from all other voices' (Calvino, qtd. in Cavarero 1). The voice is always
} 
of theoretical psychoanalysis, returns (to the body-subject) not only a reflection, but also an echo. ${ }^{4}$ In other words, the Other speaks and from there announces one of the fundamental paradoxes that enables subjection and is especially noteworthy in the domain of theories of the sonorous - the mutual exclusivity and simultaneously interdependence of the sonorous body, voice, and writing.

In the words of Jacques Lacan, "there is cause only in something that doesn't work"; 5 that is, the field of fascination (and the field of trauma) is generated in places where the expected smooth logic of reasoning according to the posited/selected code breaks down as a result of friction, grain, inconsistency, or disagreement. One of those places is certainly the place where corporeality and textuality are relationally entangled through the aspect of voice. A body that sounds - a sonorous or vocalic body ${ }^{6}$ (a body that makes sounds by producing a voice, a loud body $)^{7}$ is in a direct and, I would say, mutually exclusive relation with the issue of the subjection of the body. To put it more simply, the law of the Symbolic operates on the basis of excluding the body as the carnal, semiotic element, ${ }^{8}$ whereby, paradoxically, the semiotic element is not (completely) excluded, ${ }^{9}$ but is, quite to the contrary, included in the Law as its other side, the foundation whereupon the Symbolic is constructed, that is, as its necessary impossible (unallowable!). As the carnal, physical, physiological, pulsional element that produces the voice as a material vibration, the body appears in this context as the ground on which and for whose sake the voice as a semantic or Symbolic value acquires an illusion of the real, signifying, legislative, ${ }^{10}$ where realizing the semantic value of the message is conditioned precisely by excluding the carnal, material element of the sounds that the body produces in the pro-

the voice of someone"; Dominic Pettman, "Pavlov's Podcast: The Acousmatic Voice in the Age of MP3s", differences: A Journal of Feminist Cultural Studies, 2011, 2-3, 149.

4 Mladen Dolar, "The Burrow of Sound", differences: A Journal of Feminist Cultural Studies, 2011, 2-3, 117.

5 Jacques Lacan, The Seminar of Jacques Lacan. Book XI: The Four Fundamental Concepts of Psychoanalysis, ed. Jacques-Alain Miller, New York/London, W. W. Norton \& Company, 1998, 22.

6 Jelena Novak, op. cit., 6.

7 Cf. Roland Barthes's concept of writing aloud or vocal writing, which is discussed further below. See Roland Barthes, The Pleasure of the Text, New York, Hill and Wang, 1998, 66-67.

8 This refers to Julia Kristeva's notion of the semiotic, which is further discussed below. See Julia Kristeva, Revolution in Poetic Language, New York, Columbia University Press, 1984 and Powers of Horror: An Essay on Abjection, Columbia University Press, New York, 1982.

9 For more on the dynamic between the symbolic and the semiotic, see Julia Kristeva, Revolution in Poetic Language, op. cit. and Powers of Horror, op. cit.

10 Mladen Dolar, A Voice and Nothing More, Cambridge (MA), The MIT Press, 2006, 54. 
cess of voicing itself. ${ }^{11}$ Or, in other words, the body may be recognized in the locus of the subject only in the process of renouncing its materiality. That claim points to the following question: namely, if the body becomes a body-subject only if it renounces the body qua body-carnality, does that mean that corporeality is knowable to us only through its own (Symbolical!) concept, that is, is corporeality cognizable only through the image and the voice of the Other (or its Law)? Is it ever possible to reach (feel?) the point of the corporeal so that it does not come down to merely speaking the body, denying the (material) body its place in the coordinates of the intelligible and, by extension, cognizable? ${ }^{12}$

Those questions inevitably bring us back precisely to that missing (removed, hidden) point, that is, the place of the voice as the material sonority of the body, the place of the sonorous body as a body voicing itself (by means of its voice issuing from its raw materiality). The problem with the issue of the voice is multifaceted; in theoretical psychoanalysis, both the gaze and the voice $^{13}$ constitute objets petit $a$; in that sense, they are unattainable, intangible, and thoroughly formative in locating and directing the subject's desire (which is what places the subject in the coordinates of the Symbolic, which gives it its artificial - the only intelligible - life). However, unlike the gaze, which always implies a distance, separation (the gazed at is other to the beholder, whose gaze returns [from the Other], establishing a difference), the voice includes contact, proximity, a material feeling of producing and projecting the vocal body. ${ }^{14}$ The eye does not generate friction or grain between the materiality of the body and its environment or itself the same way that the vocal apparatus does, which, in the process of voicing, uses friction, the vibrating of the vocal chords, the oral cavity, the tongue, the lungs, the chest, the entire body emanating its voice into the surrounding environment. In Dolar's view, ${ }^{15}$ the voice is even more directly addressed to the Other and precisely that immediacy generates the persistent issue of the crisis of a subjectivity that is voicing itself, the crisis of the sonorous body in the Symbolic structure. However, that certainly does not imply that

11 Mladen Dolar provides a clear exposition and explication of that claim in Mladen Dolar, $A$ Voice and Nothing More, op. cit.

12 "This gives rise to a spontaneous opposition where voice appears as materiality opposed to the ideality of meaning. The ideality of meaning can emerge only through the materiality of the means, but the means does not seem to contribute to meaning. [...] if we speak in order to say something, then the voice is precisely that which cannot be said." Ibid., 15 .

13 In addition to the breast and faeces; see Jacques Lacan, The Seminar of Jacques Lacan, Book X: Anxiety, 1962-1963, http://www.lacaninireland.com, accessed 30 January 2013.

14 Mladen Dolar, A Voice and Nothing More, op. cit., 79.

15 Ibid. 
there is no crisis of the gazing subjectivity; on the contrary, the subject is always a subject in process (and thereby also in crisis), ${ }^{16}$ be it the process of gazing or the process of voicing (sounding, speaking). Nonetheless, in contrast to the gaze, which, due to the establishment of the Imaginary dimension in the mirror phase,${ }^{17}$ preserves the subject's wholeness by maintaining its illusion that the gaze belongs to it (which is in fact inversely proportional to the abstract quality of the gaze as such!), the voice is sensibly torn off from the body (that tearing off is felt as the vibrating of the body while it is projecting its voice into the environment, for instance, the air), in that moment tearing the body in two, in a sensuously cognizable way (the speaking body and its voice, which is now separate) and thus irreversibly becomes/remains something that does not belong to it (i.e. to the body). ${ }^{18}$ Returning to the point of inverse proportion between abstraction and illusion in the game of formulating and preserving the status of subjectivity, it is precisely the materiality of the voice that causes the inadequacy of the subject's illusion of fullness. Paradoxically, the voice fragments the subject, departs from the body, and at the point of its emergence already disappears (as a material wave - a sound that ceases to vibrate). Therefore, the voice (a product of a sonorous body) is cognizable only as an echo (of the Other), in a game where the sonorous body becomes bodily and materially exposed in an almost obscene and abject way. ${ }^{19}$ That exposure of the body stems precisely from the place of the gap - the break between the voice and the body, at the very moment before the voice is coded into a message (a meaning), whereby the Signifier inscribes its trajectory, deriving with it the coordinates of the Symbolic and the subject's place in them (the Signifier locates the body in the place of the subject, including it virtually, not materially, into its system of exchange and thereby makes it existent, cognizable). The moment of the realization/reification of that gap in the break between the body and (its) voice performs (access) to materiality precisely via the point of the break (the place of horror, the place of silence, where the image emerges!) ${ }^{20}$ the place of the disconnect between the corporeal and

\footnotetext{
${ }^{16}$ For the notion of subject in process, see Julia Kristeva, Powers of Horror, op . cit.

17 Jacques Lacan, "The Mirror Stage as Formative of the Function of the I as Revealed in Psychoanalytic Experience", in: Écrits: The First Complete Edition in English, New York / London, W. W. Norton \& Company, 2006, 93-81.

18 On the break or gap between the body that produces/performs the voice/speaking and the voice itself, see Mladen Dolar, A Voice and Nothing More, op. cit. and Slavoj Žižek, “'I Hear You with my Eyes!', or, The Invisible Master”, in: Renata Salecl and Slavoj Žižek (eds.), Gaze and Voice as Love Objects, Durham (NC)/London, Duke University Press, 1996, 90-126, and Jelena Novak, op. cit.

19 Mladen Dolar, A Voice and Nothing More, op. cit., 80.

20 Slavoj Žižek, op. cit.
} 
the textual, and the place of the (subsequent) recoding of corporeality through textuality. In other words, the place where the voice is torn (off) from the body is the place that points to and exposes the very process of symbolic coding (the Symbolic is not a given, even though it presents itself as such; the Signifier is an illusion, a deceit), ${ }^{21}$ which returns the focus on the body; moreover, the claim just made suggests that it is possible to return the focus on the body - at least for a short while - and theorize it, even though it is thereby killed once again, through symbolization (which gives it life - intelligibility - within the bounds of the Symbolic). At the same time, this supplies a possible answer to the question whether corporeality may be grasped beyond/outside/free from textuality: that answer is neither absolutely yes nor absolutely no; at the moment of speaking about corporeality, corporeality is indeed already textuality, which also applies to all kinds of thinking, semantic cognition of the body/corporeality, but on the other hand, if corporeality qua materiality may not be captured, it is still graspable, precisely in the process/moment of producing or performing the voice, in a body that is voicing itself, in a sonorous body.

The sonorous body is thus established as a sort of locus of friction or grain between the semiotic and the symbolic, that is, the corporeal and the textual. Returning to Kristeva's thesis that the semiotic (which is in this context precisely the field of carnal/material pulsion) is the necessary ground whose incomplete or, rather, (deliberately, necessarily) failed exclusion, conditions the construction of the Symbolic, which prescribes every possible/cognizable reality, ${ }^{22}$ whereby precisely the semiotic ground conditions and defines the possibility of symbolic coding (in other words, of the existence of the Symbolic as such - that is why the exclusion/ignoring/abstraction of the semiotic from the Symbolic is always necessarily incomplete, failed), it seems that the point of friction between the semiotic and the Symbolic, the material/carnal and the textual/semantic is precisely the place where/through which the Symbolic/semantic is realized/reified, the place where (text) comes to life. Since meaning is generated and enabled by this friction, it follows that precisely working with the materiality of the body may effect changes/shifts in the field of the Symbolic and that, in that case, the Symbolic is not necessarily a prison consisting of petrified, immutable relations in which the subject (and its body as the material ground of subjectivity that

\footnotetext{
${ }^{21}$ See Jacques Lacan's theoretical theses concerning the issues of the signifier and the Phallus as the ultimate Signifier.

22 This certainly concerns the Lacanian terminology of the lower-case-r real. See Jacques Lacan, The Seminar of Jacques Lacan - Book XXIII: Joyce and the Sinthome, 1975-1976, translated by Cormac Gallagher from unedited French Typescripts, http://www.lacaninireland.com, accessed 20 February 2013.
} 
disappears in the process of subjection) is condemned to a set of predetermined givens; on the contrary, the subject (especially its material corporeality) is an active agent in the system of relational performances of the dimensions of the Symbolic, Imaginary, and Real, and this is precisely the place that brings the study of the sonorous body in focus. The body that voices itself becomes a point wherefrom one may work with the semanticity of the Symbolic, wherefrom other - soft - or entirely new writings may be derived.

\section{Working with the Sonorous Body qua Working with Writing: Strategies, Possibilities and Platforms}

The potential of working with the sonorous body has been noted and relatively often directly or indirectly discussed by various theorists of language, corporeality, and textuality, that is, by theorists of writing(s). More precisely, what is theorized is the very place of the body, which is inscribed or inscribes itself in the text precisely by means of its materiality (in reality, the only thing the body may invest is its materiality, which is also all that is needed for generating semantic content - of course, on the condition of disavowing the body that is called upon in the guise of subjectivity, in the guise of the called upon, of the cognizable). However, this materiality remains/survives as the ground of the Symbolic and in it, one may hear - as noise, grain, or interference - a surplus (of materiality, of carnality) exposed to the impotence of the Signifier to semanticize it entirely. ${ }^{23}$ The sonorous body is therefore always exposed ${ }^{24}$ - in the symbolic turn, its material factual positivity is transformed into negativity, which the Symbolic attempts

${ }^{23}$ According to Mladen Dolar, the voice (as a material product, a leftover from the body) is always a matter of excess from the signifier; Mladen Dolar, A Voice and Nothing More, op. cit., 81. As such, it is a constant reminder of the impotence of the signifying structure (of the Symbolic) to perform symbolization all the way. In that failure, the symbolic structure is exposed as abstract/constructed (subject to deconstruction, transformation, transgression, collapse), whereas the voice (a material surplus) is established as the only positive ground of inherent negativity, which derives its existence (meaning) in the semanticization turn at the expense of a negativization, exclusion, ignoring (of the material body) that never quite succeeds. Or, in Mladen Dolar's words: "It [the voice] is a non-signifying remainder resistant to the signifying operations, a leftover heterogeneous to structural logic, but precisely as such it seems to present a sort of counterweight to differentiality; the differential logic always refers to absence, while the voice seems to embody a presence, a background for differential traits, a positive basis for their inherent negativity. To be sure, its positivity is extremely elusive - just the vibrations of air which vanish as soon as they are produced, a pure passing, not something that could be fixed or something that one could hold on to, since one can only fix the differences, as phonology has exhaustively done"; Mladen Dolar, A Voice and Nothing More, op. cit., 36.

24 Ibid., 80. 
to hide (to derive it as negativity) in the process of deriving meaning, in the process of symbolization. Still, the materiality of the body in the voice is something that, as I argued above, may be heard, while, on the other hand, it constitutes the ground and means whereby the semantic component of language/textuality is supported/maintained, as well as, potentially, altered. Therefore, working with the carnal aspect of corporeality realizes/reifies the body's potential to inscribe its presence into the text, to use the text, whilst balancing at the very edge of fetishization and/or ecstasy, ${ }^{25}$ potentially to modify the structure of the Symbolic.

Pursuing the trajectory of corporeality's entanglement with textuality, Lacan notes a subtext of language, which he terms lalangue. ${ }^{26}$ In fact, lalangue would be the sonority of language that diverges from language as a carrier of meaning. ${ }^{27}$ In that sense, the friction of the (bodily) grain of lalangue in language becomes that which realizes/reifies language as a means of uttering messages, in such a way as to provoke the awareness of inscribing a specific body (every body is a separate bodily-textual position) in the language spoken by that body. Lalangue is that which enables pleasure in (material) language, that which takes pleasure in language; that which enjoys language as such. Assuming a completely transgressive stance, lalangue consumes language in an individual way; it modifies language by means of sonority, from which there is no escape (just as there is no escape from the impotence and failure of the structure of language). Lalangue is a vocal surplus, an object inside the signifier, an object that is enjoyed and an object that enjoys (consumes [language]). In Dolar's words: "It is as if the object, the object voice, and hence enjoyment, became integrated into the signifier, but integrated in such a way that their divergence is what drives lalangue". ${ }^{28}$ Therefore, working with the platform of lalangue opens the potential of working with the semantic dimension of language by way of working with the grain of the body (without which there is no platform of the symbolic/semanticizing either), which, in turn, introduces the possibility of potential modifications as well as transgressions of the linguistic structure. In other words, lalangue is one of the strategies of focusing on corporeality entangled with textuality, whereby

${ }^{25}$ For ways whereby the voice that eludes semanticization is pacified by being turned into a fetish object or provokes, for the same reason, ecstasy, see Mladen Dolar, A Voice and Nothing More, op. cit.

26 In the same work, Dolar elaborates on lalangue in the domain of the sonorous.

27 Not differs, in terms of there being a distance from language in an a:b proportion, but $d i$ verges, in terms of being present and entangled in language so much that it is separated from it only by points of differences (whose frictions with language are precisely manifested as lalangue) in an a:a.varied (a.divergent) proportion.

28 Ibid., 144. 
one may perhaps attain a change, a shift of fixed points along the coordinates of semanticization.

Kristeva notes a similar interdependence between the corporeal as carnal and the textual as semanticizing, and dubs those platforms the semiotic (presymbolic, extra-symbolic, corporeal, pulsional) and the symbolic (linguistic, semantic, signifying). ${ }^{29}$ Although in the process of subjection (of recognizing the subject in the structure that was already prepared for it), the symbolic codes the semiotic ground, inscribing itself into it and obscuring it, ${ }^{30}$ the semiotic does not disappear in that code; on the contrary, as Kristeva also notes, it remains actively present as the other side of the Symbolic, as the grain of the body, whose acting, similarly to lalangue, reifies and enables the linguistic message. The boundary between the symbolic and the semiotic is thus permeable and walking along it is precisely the place where the sonorous body operates, which thus directly participates in the dynamic of the inscription of meaning. Kristeva's term for this dynamic of the divergence of writing(s) is poetic language, which she views as a powerful tool for resisting, changing, and transgressing the rigid structure and law of the Symbolic. ${ }^{31}$ Poetic language thus becomes another possibility of language, always present and open in its perpetual multi-dimensionalization, whereby language, retaining the faculty of communication, acquires a heterogeneous quality, quite different from the homogenizing symbolic structure. A body breathing in language may also be identified in the concept of geno-text, elaborated by Kristeva and Roland Barthes, ${ }^{32}$ which is likewise directly related to the capacities and transformative potentials of the sonorous body, being that which is by-linguistic - not a matter of language as a means of communica-

29 See Julia Kristeva, Powers of Horror, op. cit. and Julia Kristeva, Revolution in Poetic Language, op cit.

${ }^{30}$ In this case, the semiotic ground is not hidden - it is not removed, entirely covered, but only obscured - repressed only as much as the symbolic is able to accomplish (the Lacanian Real, which is closely related to Kristeva's semiotic, is never entirely repressed from the structure of the Symbolic, which rejects it, which is horrified by it, which does not allow it, and which, searching for it in a kind of paradox, uses it to distinguish itself, to constitute itself, and take pleasure in that difference). For a more detailed discussion of the relation between the semiotic and the Real, see Dragana Stojanović, Interpretacije mapiranja ženskog tela u tekstualnim prostorima umetnosti i kulture, Belgrade, Orion Art / Fakultet za medije i komunikacije, 2015.

31 Julia Kristeva, Revolution in Poetic Language, op. cit.

32 See related discussions in Leon S. Roudiez, "Introduction", in: Desire in Language: A Semiotic Approach to Literature and Art by Julia Kristeva, New York, Columbia University Press, 1980, 1-20 and in Roland Barthes, The Pleasure of the Text, op. cit. 
tion but as an organ. ${ }^{33}$ Barthes even explicitly calls this kind of writing writing aloud, pointing to the sonorous body as that which brings difference (to the issue of understanding, communication, (re)semantization): "Writing aloud is not expressive; it leaves expression to the pheno-text, to the regular code of communication; it belongs to the geno-text, to significance; it is carried not by dramatic inflections, subtle stresses, sympathetic accents, but by the grain of the voice [...] writing aloud is not phonological but phonetic; its aim is not the clarity of messages, the theater of emotions; what it searches for (in a perspective of bliss) are the pulsional incidents, the language lined with flesh, a text where we can hear the grain of the throat, the patina of consonants, the voluptuousness of vowels, a whole carnal stereophony: the articulation of the body, of the tongue, not that of meaning, of language". 34

Each one of those theoretical concepts (lalangue, the semiotic, geno-text, writing aloud) points to the place of the punctum of the sonorous text. ${ }^{35}$ The punctum represents a point that tears through smooth perception, being the surplus, error, or elusion. The punctum is the very point of difference between corporeality and textuality, a painful (pierced!) ${ }^{36}$ point on the body that invests its materiality into performing the reading of the text, that exposes itself to the text, and resists penetration by the signifying practice. In the context of the sonorous text, what hurts is the sonorous body, which is invested into the sonorous text it produces/performs, so that it may, at the moment when it is torn off from the body, surrender it to symbolization. However, that surrender is never complete (neither is symbolization) - the Real(ity) of the vibration of the sonorous body, that noise/grain/friction of the voice, the simultaneous friction of the throat against the cutting edge of the semanticization process and against its own humming flesh derives the borderline of the entanglement of the semiotic and the symbolic, of lalangue and langue, of the corporeal and the textual, working with a sort of ground zero ${ }^{37}$ of a sonorous writing that generates a materiality of textuality and a textuality of materiality, constantly challenging the autonomy of

33 Roland Barthes, The Pleasure of the Text, op. cit, 67. Cf. Roland Barthes, Fragmenti ljubavnog diskursa, Zagreb, Pelago, 2007, 74.

34 Roland Barthes, The Pleasure of the Text, op. cit., 66-67.

35 The term punctum comes here from Roland Barthes, who uses the example of visual perception to explain it and applies it to the domain of the sonorous in the same capacity. See Roland Barthes, Camera Lucida: Reflections on Photography, New York, Hill and Wang, 1982.

36 Cf. Hélène Cixous, "Preface: On Stigmatexts by Hélène Cixous" in: Stigmata: Escaping Texts, London / New York, Routledge, 2005, x-xiii.

37 Cf. Roland Barthes, Writing Degree Zero, New York, Hill and Wang, 1967. 
both and generating space for work in (sonorous) language. Language no longer appears like a cage, but as the horizon of the possible (with the plaisir and jouissance of language working in conjunction). ${ }^{38}$

In practical application, these dialogues along the trajectory of the ground zero of sonorous writing would involve working with pleasure in sonorous writing; working with transgressions of writing in the domain of sound; working with the disallowed (or working with the limits of the allowable in the intelligible code of sonorous writing); working with silence (not with silence as a pause or break - with coded semanticized silence - but with silence as a spasm, aphonia, the Real, with an ecstasy that cannot be fetishized, working with the silence of the sonorous body); working with breath (to breathe means to live or experience sound with one's body); working with pre-linguistic and by-linguistic materials (to hiccup, stutter, scream, sing beside the expected code (and in parallel with it), to write with laughter). ${ }^{39}$ To count on the gap between the sonorous body and the voice; to re-imagine the relationship between the body and (its) voice; ${ }^{40}$ to focus on the affective and not beware its entanglement with the text (to enjoy the affective in the text, through the text, by the text, and with the text) $;{ }^{41}$ to produce soft writings; to produce other writings; to produce $d i$ vergent writings; to inscribe (one's) body into sonorous language (and into all other kinds of language!), because the body is never the erased place of writing; on the contrary, the body is the place where writing is performed (and the place where writing performs itself!), the place of working with writing, the place of a re-semanticization, of a reform of writing. The body is that point wherefrom writing begins, a point that is never (entirely) lost; therefore, the body is the place of the very threshold of writing; the place that always resounds with new possibilities.

\footnotetext{
${ }^{38}$ For more on the concepts of plaisir and jouissance, see Roland Barthes, The Pleasure of the Text, op. cit.

39 Cf. Hélène Cixous, "La", in: Susan Sellers (ed.), The Hélène Cixous Reader, London, Routledge, Taylor \& Francis Group, 2000, 59-61; Luce Irigaray, This Sex Which is Not One, Ithaca (NY), Cornell University Press, 1985; Anne Pellegrini, "(Laughter)", in: Patrick Campbell and Adrian Kear (eds.), Psychoanalysis and Performance, New York, Routledge, 2001, 177-191.

40 This thesis is elaborated in detail in Jelena Novak, op. cit.

41 See a constructive discussion of the issue of the relationship between the corporeal and the textual as the affective and the semantic in Ana Hofman, Glasba, politika, afekt: novo življenje partizanskih pesmi v Sloveniji, Ljubljana, Založba ZRC, 2015, 47-57.
} 